\title{
The Impact of Total Bank Assets, Income Diversification, and Financial Inclusion on the Stability of Islamic Commercial Banks in Indonesia With a Moderating Variable for the 2014-2019 Capital Buffer
}

\author{
Baby Ayu Bellya Putrie $^{1} \&$ Ratna Mappanyukki ${ }^{1}$ \\ ${ }^{1}$ Mercubuana University, Indonesia \\ Correspondence: Baby Ayu Bellya Putrie, Mercubuana University, Indonesia. E-mail: itsbabyputrie@gmail.com
}

Received: December 20, 2021

Accepted: January 12, 2022

Online Published: January 26, 2022

doi:10.20849/ajsss.v7i1.990

URL: https://doi.org/10.20849/ajsss.v7i1.990

\begin{abstract}
For the five-year period 2014-2019, to determine and empirically demonstrate the influence of total bank assets on the stability of Islamic commercial banks in Indonesia, with the moderating variable of capital buffer. Sample size was determined using a purposive sampling approach, which included eight Islamic Commercial Banks. Using Moderated Regression Analysis to test hypotheses (MRA). As a result of these findings, it can be concluded that Islamic commercial banks in Indonesia are more stable if they have more diverse sources of income and greater financial inclusion. Islamic commercial banks in Indonesia's capital buffer can moderate the impact of income diversification on stability with the type of moderation generated by pure moderator, which indicates that stability can be improved. This is despite the fact that Islamic Commercial Banks' capital buffers are unable to counteract the negative effects of total assets and financial inclusion on their stability.
\end{abstract}

Keywords: total asset, incoming diversification, financial inclusion, capital buffer

\section{Introduction}

It is possible that financial inclusion will modify the structure of the system in terms of the transactions, services, and access points that are made available to the general public. There will be new risks and shocks to the financial system as a result of these changes, which might lead to greater levels of financial instability, such as the failure of a number of smaller financial institutions. But on the other hand, financial inclusion can change the composition of the financial system in terms of transactions, services and access points available to the public which in turn will create new potential risks or shocks that tend to cause financial instability such as the collective failure of smaller institutions that can significantly can have a negative effect on stability in the financial system (Fauziah et al., 2020).

Income diversification as an internal factor is carried out by Islamic Banks in an effort to maximize their performance so that their business stability is stronger. Banks that can diversify their income through non-financing income are able to provide benefits in reducing risk which will have a good impact on business stability. Based on research by Cihak and Hesse (2008), Wahid and Dar (2016), and Wibowo (2016) concluded that income diversification has a positive relationship with the stability of Islamic banks.

Therefore, due to the vulnerabilities of Islamic banks in facing competition risks and risks arising from the diversification strategy activities it implements, Bank Indonesia also plays a role in maintaining the stability of Islamic banks by setting a minimum capital ratio that must be maintained by Islamic banks based on a risk profile that is faced. However, Islamic banks often try to maintain their capital ratio above the required capital buffer.

However, capital regulation is beneficial for the safety and soundness of banks, requiring banks to withstand capital increases which have a lot of costs and can be a constraint related to bank behavior. If the cost of capital in times of financial difficulty is low and the cost of getting fresh capital is high, the capital buffer can serve as a risk-absorber for a variety of problems that may occur. 


\section{Total Bank Assets}

The total assets of a corporation may be considered a measure of the company's size. The capacity and degree of risk in managing assets provided by shareholders to promote investor prosperity is typically determined by the size of the company in order to gauge the skill and expansion potential of a corporation (Haryanto, 2015). Companies with large total assets reflect the company's stability. Therefore, the total assets can be known by calculating through the following formula, i.e.:

\section{Asset Total = Logarithm (Asset Total)}

\subsection{Income Diversification}

Income from bank activities is divided into two parts, namely interest income and non-interest income. Interest income is bank operating income obtained from traditional activities for distributing funds in the form of credit to other parties outside the bank, while non-interest income is income obtained from non-traditional activities aimed at supporting and facilitating activities to raise funds and distribute funds. by providing other supporting services. (Sianipar, 2015 and Ramadhanti, 2016). To measure the level of diversification for Islamic banks. The value can be found by the formula:

$$
\begin{aligned}
\mathrm{HHI}= & 1-\left(\text { \SH } \ \wedge^{\wedge} \mathrm{NET}+\llbracket \mathrm{SH} \rrbracket \wedge 2 \mathrm{NON}\right) \\
& \mathrm{SHNET}=\mathrm{NET} /(\mathrm{NET}+\mathrm{NON}) \\
& \text { SHNON }=\mathrm{NON} /(\mathrm{NET}+\mathrm{NON})
\end{aligned}
$$

Information:

$\begin{array}{ll}\text { HHI } & : \text { Level of diversification of income sources } \\ \text { SHNET } & : \text { Net financing income share of total revenue } \\ \text { SHNON } & : \text { Non-financing income share of total income } \\ \text { NET } & : \text { Income from financing activities } \\ \text { NON } & : \text { Income from non-financing activities. }\end{array}$

\subsection{Capital Buffer}

\section{Definition of capital buffer}

Capital buffer is the gap between a bank's capital adequacy ratio (CAR) and the regulatory authority's minimum banking capital requirements. (Anggitasari, 2013).

\section{Capital Buffer Measurement}

In accordance with Bank Indonesia regulations, the minimum capital requirement ratio is $8 \%$ of risk-weighted assets. Mathematically, according to Wibowo, (2016: 183), the capital buffer can be formulated as follows:

$$
\mathrm{CB}=\mathrm{Ki}, \mathrm{t}-\mathrm{KrI}, \mathrm{t}
$$

Information:

CB : Capital buffer.

$\mathrm{Ki}, \mathrm{t}:$ Islamic bank capital adequacy ratio-i in year-t.

$\mathrm{KrI}, \mathrm{t}$ : Minimum capital adequacy ratio according to risk profile

\section{Research Design and Methods}

\subsection{Types of Research}

Researching how one variable affects another is the goal of causal research. All Indonesian Islamic Commercial Banks registered with Bank Indonesia and the Financial Services Authority since 2014 have been included in this study.

\subsection{Population and Sample}

All Islamic Commercial Banks registered with Bank Indonesia and the Financial Services Authority between 2014 and 2019 are included in this study, which takes a census method. According to Bank Indonesia and the Financial Services Authority, there are now 11 registered Islamic commercial banks in Indonesia.

\subsection{Data Collection Technique}

Researchers obtained research data sourced from: 
a) Library research

b) Secondary Data Research

\subsection{Data Analysis Method}

In this study, descriptive analysis was used, followed by moderated regression analysis for verification (MRA).

\section{Results and Discussion}

OJK's website was used in this study, which focused on Islamic Commercial Banks that have produced audited financial reports for a period from 2014 to 2019, using secondary data. With a controlled variable capital buffer and total assets, income diversification and financial inclusion explain the stability of Islamic Commercial Banks in Indonesia between 2014 and 2019.

\subsection{Descriptive Statistics}

Based on the results of data processing, the results of descriptive statistical analysis are obtained, as follows:

Table 1. Descriptive statistics

\begin{tabular}{cccccc}
\hline & Total Asset & $\begin{array}{c}\text { Income } \\
\text { Diversification }\end{array}$ & $\begin{array}{c}\text { Financial } \\
\text { Inclusion }\end{array}$ & $\begin{array}{c}\text { Capital } \\
\text { Buffer }\end{array}$ & $\begin{array}{c}\text { Stabilitas Bank } \\
\text { Syariah }\end{array}$ \\
\hline Mean & 13.30375 & 0.224167 & 23.38250 & 11.39521 & 3.941250 \\
\hline Median & 13.35500 & 0.185000 & 20.99500 & 10.58500 & 2.320000 \\
\hline Maximum & 14.05000 & 0.500000 & 46.41000 & 30.28000 & 10.64000 \\
\hline Minimum & 12.48000 & 0.010000 & 6.350000 & 2.340000 & 0.430000 \\
\hline Std. Dev. & 0.434979 & 0.151346 & 10.84861 & 6.562568 & 3.276833 \\
\hline Skewness & -0.116455 & 0.422045 & 0.507685 & 0.973457 & 0.610686 \\
\hline Kurtosis & 1.815205 & 2.046887 & 2.574020 & 3.961603 & 1.756593 \\
\hline Jarque-Bera & 2.915970 & 3.241822 & 2.424871 & 9.430316 & 6.075625 \\
\hline Probability & 0.232705 & 0.197719 & 0.297472 & 0.008958 & 0.047940 \\
\hline Sum & 638.5800 & 10.76000 & 1122.360 & 546.9700 & 189.1800 \\
\hline Sum Sq. Dev. & 8.892725 & 1.076567 & 5531.540 & 2024.163 & 504.6687 \\
\hline Observations & 48 & 48 & 48 & 48 & 48 \\
\hline
\end{tabular}

Source: Eviews Data Processing Results, 2021

Based on Table 1 descriptive statistics, the results of statistical descriptive analysis of 8 companies as a sample regarding the variables in this study, the descriptive results obtained are as follows:

1) The total asset variable as the independent variable obtained an average result of 13.30375, with a standard deviation of 0.434979 . The highest total asset value was obtained at 14,05000 at Bank Mandiri Syariah for the 2019 period, while the lowest total asset value was obtained at 12,48000 at Bank BCA Syariah for the 2014 period, overall total assets during the 2014-2019 period at Islamic banks obtained results a total of 638,5800 .

2) The income diversification variable as an independent variable obtained an average result of 0.224167 , with a standard deviation of 0.151346 . The highest income diversification value was obtained at 0.5000000 at Bank Aceh for the 2016 period, while the lowest income diversification value was obtained at 0.010000 at Bank BTPN Syariah for the 2014-2019 period, overall income diversification during the 2014-2019 period at Islamic Banks obtained the total result is 10,76000.

3) The financial inclusion variable as the independent variable obtained an average result of 23.38250, with a standard deviation of 10.84861. The highest financial inclusion value was obtained at 46,41000 at Bank Mega Syariah for the 2014 period, while the lowest financial inclusion value was obtained at 6.350000 at Bank BTPN Syariah for the 2019 period, overall financial inclusion during the 2014-2019 period at Sharia Bank obtained results a total of 1122,360. 
4) The capital buffer variable as a moderating variable obtained an average result of 11,39521, with a standard deviation of 6.562568. The highest capital buffer value was obtained at 30.28000 at Bank BCA Syariah for the period of 2019, while the lowest capital buffer value was obtained at 2.340000 at Bank Muamalat in the 2018 period. Overall, the capital buffer during the period 2014-2019 at Islamic banks obtained a total return. amounted to 546,9700 .

5) The Islamic bank stability variable as the dependent variable obtained an average result of 3.941250, with a standard deviation of 3.276833. For the highest value of Islamic Bank stability, it was obtained at 10.64000 at BNI Syariah Bank for the period of 2019, while the lowest Syariah Bank Stability value was obtained at 0.430000 at Mega Syariah Bank in 2014 period. total yield of 189.1800.

\subsection{Normality Test}

The following are the results of the normalcy test, which are derived from the data processing results:

Table 2. Normality Test Results

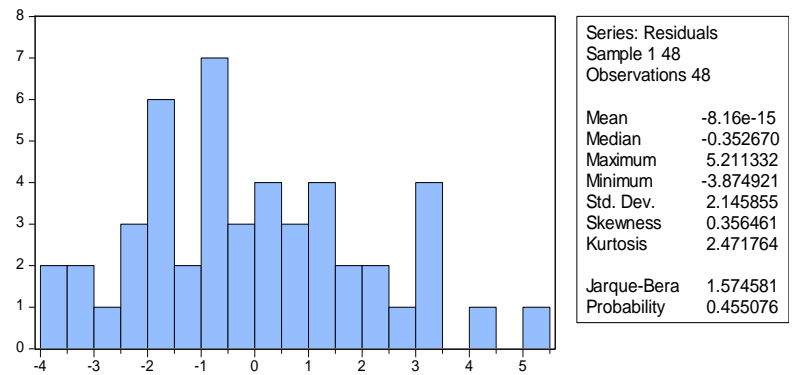

Source: Eviews Data Processing Results, 2021

To infer that this study data is normally distributed, we may use the Jarque-Fallow test with a 0.455076 probability and the probability of 0.455076 being greater than 0.05 . (See Table 2).

\subsection{Multicollinearity Test}

The findings of the multicollinearity test, as a consequence of data processing, as follows:

Table 3. Multicollinearity Test Results

\begin{tabular}{cccc}
\hline & Coefficient & Uncentered & Centered \\
\hline Variable & Variance & VIF & VIF \\
\hline $\mathrm{C}$ & 301.1628 & 2011.351 & $\mathrm{NA}$ \\
\hline Total Asset & 1.547765 & 1831.446 & 1.915072 \\
\hline $\begin{array}{c}\text { Disversifikasi } \\
\text { Pendapatan }\end{array}$ & 8.142652 & 3.952413 & 1.219697 \\
\hline $\begin{array}{c}\text { Inklusi } \\
\text { Keuangan }\end{array}$ & 0.001485 & 6.566228 & 1.143075 \\
\hline Capital Buffer & 0.006889 & 7.914936 & 1.940308 \\
\hline
\end{tabular}

Source: Eviews Data Processing Results, 2021

According to the multicollinearity test findings shown in Table 3 above, this study is free of multicollinearity issues. There is no evidence of multicollinearity in this study, as shown by the Cendered VIF values, which are all less than 10 .

\subsection{Heteroscedasticity Test}

Following data processing, the heteroscedasticity test yielded the following results: 
Table 4. Heteroscedasticity Test Results

\begin{tabular}{cccc}
\hline \multicolumn{4}{c}{ Heteroskedasticity Test: Glejser } \\
\hline F-statistic & 0.529958 & Prob. F(7,40) & 0.8065 \\
\hline $\begin{array}{c}\text { Obs*R-sq } \\
\text { uared }\end{array}$ & 4.073831 & Prob. Chi-Square(7) & 0.7712 \\
\hline $\begin{array}{c}\text { Scaled } \\
\text { explained }\end{array}$ & 3.965763 & Prob. Chi-Square(7) & 0.7837 \\
SS & & & \\
\hline
\end{tabular}

Source: Eviews Data Processing Results, 2021

In light of the glesjer test findings and an Obs*R-squared probability of 0.7712 , it is possible to infer that this study does not have a heteroscedasticity issue. This study does not have a heteroscedasticity concern because the findings are $0.7712>0.05$.

\subsection{Autocorrelation Test}

The following are the findings of the autocorrelation test, which are derived from the results of data processing:

Table 5. Autocorrelation Test Results

\begin{tabular}{cccc}
\hline R-squared & 0.747744 & $\begin{array}{c}\text { Mean dependent } \\
\text { var }\end{array}$ & 3.941250 \\
\hline $\begin{array}{c}\text { Adjusted } \\
\text { R-squared }\end{array}$ & 0.688000 & S.D. dependent var & 3.276833 \\
\hline $\begin{array}{c}\text { S.E. of } \\
\text { regression }\end{array}$ & 1.830340 & $\begin{array}{c}\text { Akaike info } \\
\text { criterion }\end{array}$ & 4.242765 \\
\hline $\begin{array}{c}\text { Sum squared } \\
\text { resid }\end{array}$ & 127.3055 & Schwarz criterion & 4.632599 \\
\hline $\begin{array}{c}\text { Log } \\
\text { likelihood }\end{array}$ & -91.82637 & $\begin{array}{c}\text { Hannan-Quinn } \\
\text { criter. }\end{array}$ & 4.390084 \\
\hline F-statistic & 12.51565 & Durbin-Watson stat & 1.789913 \\
\hline $\begin{array}{c}\text { Prob(F-statis } \\
\text { tic) }\end{array}$ & 0.000000 & & \\
\hline
\end{tabular}

Source: Eviews Data Processing Results, 2021

In accordance with Table 5 above, the results of the autocorrelation test were obtained with a dw value of 1.789913, which was then compared with the values of $\mathrm{dl}$ and du in the Durbin Watson table, with $\mathrm{k}=4$ and $\mathrm{n}=$ 48 , and the results were obtained with $\mathrm{dl}=1.3619$ and $\mathrm{du}=1.7206$, which means that there is no autocorrelation problem in this study. Because the results of du d4-du (1.7206-1)

4.6 Panel Data Regression Analysis

\subsubsection{Common Effect Model (CEM)}

Based on the results of data processing, the results of the common effect model (CEM) model are obtained, as follows: 
Table 6. Common Effect Model Estimation

\begin{tabular}{|c|c|c|c|c|}
\hline Variable & $\begin{array}{c}\text { Coefficien } \\
t\end{array}$ & Std. Error & t-Statistic & Prob. \\
\hline $\mathrm{X} 1$ ? & 1.019004 & 0.261587 & 3.895475 & 0.0004 \\
\hline $\mathrm{X} 2 ?$ & -27.24092 & 7.267940 & -3.748094 & 0.0006 \\
\hline $\mathrm{X} 3 ?$ & -0.216909 & 0.097106 & -2.233742 & 0.0310 \\
\hline $\mathrm{Z}$ ? & 2.034376 & 1.119787 & 1.816753 & 0.0766 \\
\hline $\mathrm{X} 1 \mathrm{Z}$ ? & -0.187357 & 0.094610 & -1.980300 & 0.0544 \\
\hline $\mathrm{X} 2 \mathrm{Z} ?$ & 2.103269 & 0.593300 & 3.545034 & 0.0010 \\
\hline X3Z? & 0.006366 & 0.008969 & 0.709721 & 0.4819 \\
\hline R-squared & 0.532445 & $\begin{array}{c}\text { Mean } \\
\text { dependent } \\
\text { var }\end{array}$ & 3.941044 & \\
\hline $\begin{array}{c}\text { Adjusted } \\
\text { R-squared }\end{array}$ & 0.464022 & $\begin{array}{c}\text { S.D. } \\
\text { dependent } \\
\text { var }\end{array}$ & 3.276429 & \\
\hline $\begin{array}{l}\text { S.E. of } \\
\text { regression }\end{array}$ & 2.398691 & $\begin{array}{l}\text { Akaike } \\
\text { info } \\
\text { criterion }\end{array}$ & 4.721761 & \\
\hline $\begin{array}{c}\text { Sum squared } \\
\text { resid }\end{array}$ & 235.9025 & $\begin{array}{l}\text { Schwarz } \\
\text { criterion }\end{array}$ & 4.994645 & \\
\hline Log likelihood & -106.3223 & $\begin{array}{l}\text { Hannan- } \\
\text { Quinn } \\
\text { criter. }\end{array}$ & 4.824884 & \\
\hline $\begin{array}{c}\text { Durbin-Watso } \\
n \text { stat }\end{array}$ & 0.341084 & & & \\
\hline
\end{tabular}

Source: Eviews Data Processing Results, 2021

Based on the table above, there are two variables with an individual test (t-test probability) which looks significant with $=5 \%$ and the adjusted R2 value is 0.464022 . means that the model is significant. And the Durbin-Watson stat value is 0.341084 which is not close to the range of number 2 . The disturbance variable is expected to explain the difference between the intercept and the slope if both are assumed to be constant over time using this estimation approach (error or residual).

\subsubsection{Fixed Effect Models (FEM)}

The following are the results of the fixed effect model (FEM), which are derived from the data processing results:

Table 7. Fixed Effect Model Estimation

Dependent Variable: Y?

Method: Pooled Least Squares

Date: 06/12/21 Time: 04:57

Sample: 20142019

Included observations: 6

Cross-sections included: 8

Total pool (balanced) observations: 48

Variable Coefficient Std. Error t-Statistic Prob.




\begin{tabular}{ccccc}
\hline $\mathrm{C}$ & -62.31898 & 24.30898 & -2.563620 & 0.0151 \\
\hline $\mathrm{X} 1 ?$ & 5.199467 & 1.826034 & 2.847411 & 0.0075 \\
\hline $\mathrm{X} 2 ?$ & -5.623478 & 2.972448 & -1.891868 & 0.0673 \\
\hline $\mathrm{X} 3 ?$ & -0.048830 & 0.049952 & -0.977543 & 0.3354 \\
\hline $\mathrm{Z} ?$ & 0.759245 & 1.326755 & 0.572257 & 0.5710 \\
\hline $\mathrm{X} 1 \mathrm{~T} ?$ & -0.082869 & 0.100263 & -0.826519 & 0.4144 \\
\hline $\mathrm{X} 2 \mathrm{Z} ?$ & 0.644299 & 0.249059 & 2.586932 & 0.0143 \\
\hline $\mathrm{X} 3 Z ?$ & 0.006653 & 0.003988 & 1.668222 & 0.1047 \\
\hline
\end{tabular}

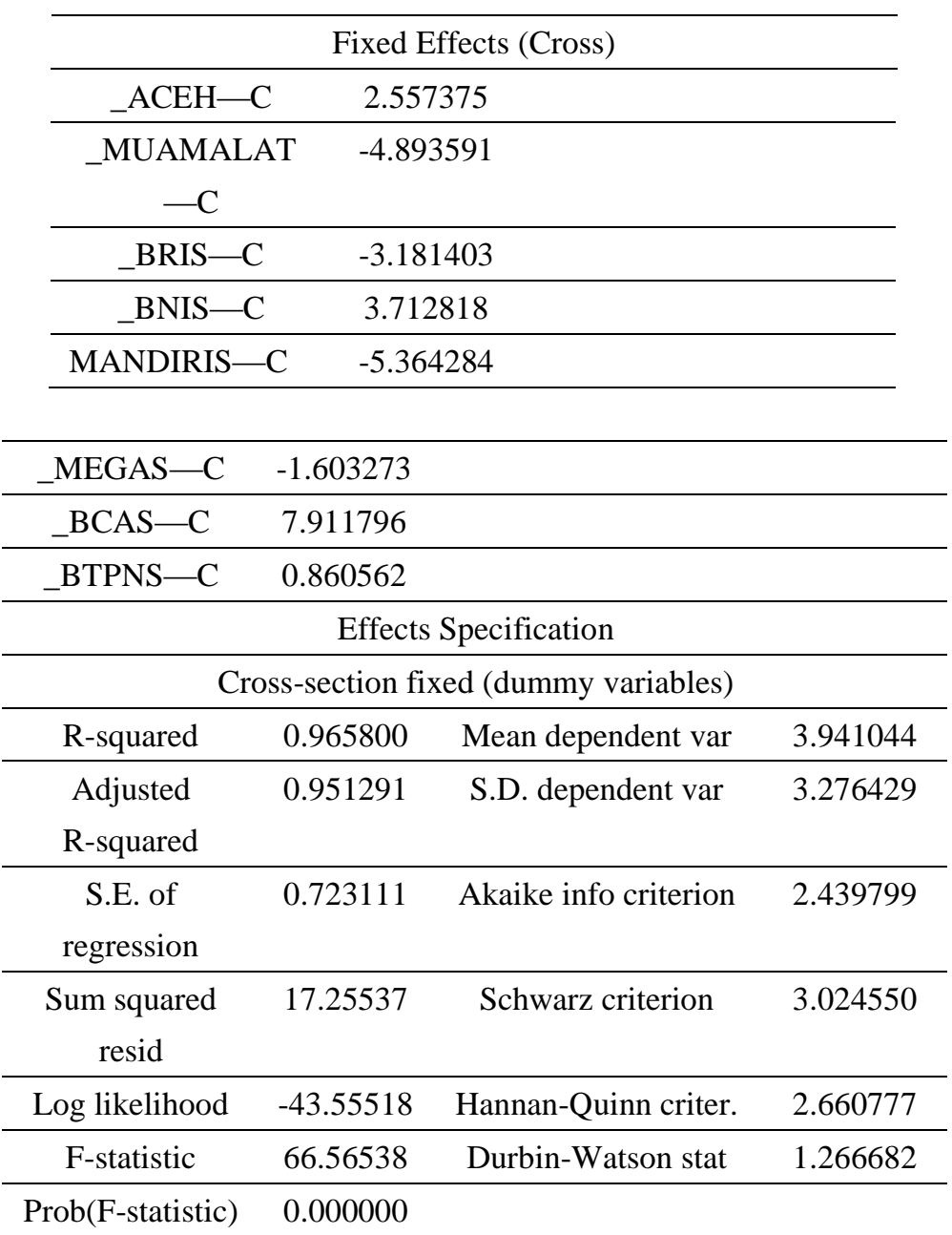

Source: Eviews Data Processing Results, 2021

In the table above, it can be seen that the t-stat test contains two variables that show significance $(\alpha=5 \%)$. Next, the adjusted R2 value is 0.965800 . The probability value of the f-stat of 0.000000 means that the model is significant. And the Durbin-Watson stat value of 1.266682 which is not close to the 2 range.

In this estimation approach, regardless of individual dimensions and time, it is assumed that the behavior of the data between regions is the same in various time periods

\subsubsection{Random Effect Model (REM)}

The following are the outcomes of the random effect model (REM) model, which are derived from the data processing results: 
Table 8. Random Effect (REM) Model Test Results

Dependent Variable: Y?

Method: Pooled EGLS (Cross-section random effects)

Date: 06/12/21 Time: 04:57

Sample: 20142019

Included observations: 6

Cross-sections included: 8

Total pool (balanced) observations: 48

Swamy and Arora estimator of component variances

\begin{tabular}{ccccc}
\hline Variable & Coefficient & Std. Error & t-Statistic & Prob. \\
\hline $\mathrm{C}$ & -55.19706 & 8.976103 & -6.149334 & 0.0000 \\
\hline $\mathrm{X} 1 ?$ & 5.185815 & 0.682177 & 7.601863 & 0.0000 \\
\hline $\mathrm{X} 2 ?$ & -33.65592 & 2.426674 & -13.86916 & 0.0000 \\
\hline $\mathrm{X} 3 ?$ & -0.186245 & 0.029695 & -6.271891 & 0.0000 \\
\hline $\mathrm{Z} ?$ & 5.579926 & 0.668126 & 8.351602 & 0.0000 \\
\hline $\mathrm{X} 1 \mathrm{Z} ?$ & -0.458508 & 0.052515 & -8.731061 & 0.0000 \\
\hline $\mathrm{X} 2 \mathrm{Z} ?$ & 2.640635 & 0.199063 & 13.26533 & 0.0000 \\
\hline
\end{tabular}

\begin{tabular}{|c|c|c|c|}
\hline X3Z? & 0.004405 & $0.002723 \quad 1.618060$ & 0.1135 \\
\hline \multicolumn{4}{|c|}{ Random Effects (Cross) } \\
\hline _ACEH-C & $8.96 \mathrm{E}-10$ & & \\
\hline $\begin{array}{c}\text { _MUAMALAT } \\
-\mathrm{C}\end{array}$ & $-1.18 \mathrm{E}-09$ & & \\
\hline _BRIS-C & $-3.70 \mathrm{E}-10$ & & \\
\hline _BNIS-C & $4.73 \mathrm{E}-09$ & & \\
\hline _MANDIRIS_C & $-1.65 \mathrm{E}-09$ & & \\
\hline _MEGAS-C & $-5.31 \mathrm{E}-10$ & & \\
\hline _BCAS-C & $2.01 \mathrm{E}-09$ & & \\
\hline _BTPNS-C & $-3.91 \mathrm{E}-09$ & & \\
\hline \multicolumn{4}{|c|}{ Effects Specification } \\
\hline & & S.D. & Rho \\
\hline Cross-se & ction random & $1.14 \mathrm{E}-05$ & 0.0000 \\
\hline Idiosync & ratic random & 0.723111 & 1.0000 \\
\hline \multicolumn{4}{|c|}{ Weighted Statistics } \\
\hline R-squared & 0.571634 & Mean dependent var & 3.941044 \\
\hline $\begin{array}{c}\text { Adjusted } \\
\text { R-squared }\end{array}$ & 0.496670 & S.D. dependent var & 3.276429 \\
\hline S.E. of regression & 2.324488 & Sum squared resid & 216.1298 \\
\hline F-statistic & 7.625437 & Durbin-Watson stat & 0.502550 \\
\hline Prob(F-statistic) & 0.000008 & & \\
\hline \multicolumn{4}{|c|}{ Unweighted Statistics } \\
\hline R-squared & 0.571634 & Mean dependent var & 3.941044 \\
\hline $\begin{array}{l}\text { Sum squared } \\
\text { resid }\end{array}$ & 216.1298 & Durbin-Watson stat & 0.502550 \\
\hline
\end{tabular}

Source: Eviews Data Processing Results, 2021 
In the table above, it can be seen that the t-stat test contains two variables that show significance $(\alpha=5 \%)$. The adjusted R2 value is 0.496670 . The probability value of the f-stat of 0.000008 means that the model is significant. As well as the Durbin-Watson stat value of 0.502550 which is not close to the 2 range. In this estimation approach, panel data is based on differences in intercept and slope as a result of differences between individuals or objects.

4.6.4 Chow Test

The following are the findings of the Chow test, which are derived from the data processing results:

Table 9. Chow Test

\begin{tabular}{lccc}
\hline \multicolumn{4}{c}{ Redundant Fixed Effects Tests } \\
\hline \multicolumn{4}{c}{ Pool: DATAPOOL } \\
\hline \multicolumn{4}{c}{ Test cross-section fixed effects } \\
\hline Effects Test & Statistic & d.f. & Prob. \\
\hline \multicolumn{4}{c}{} \\
\hline Cross-section F & 54.333863 & $(7,33)$ & 0.0000 \\
\hline $\begin{array}{l}\text { Cross-section } \\
\text { Chi-square }\end{array}$ & 121.332278 & 7 & 0.0000 \\
\hline
\end{tabular}

Source: Eviews Data Processing Results, 2021

Based on the findings of the Chow test, which yielded a chi-square cross-section probability value of 0.0000 , and the results of $0.0000<0.05$, it can be concluded that Ho is rejected and $\mathrm{Ha}$ is accepted, indicating that the fixed effect model was chosen correctly. On the basis of the Chow test findings, it is determined that the fixed effect (FEM) model is the best model, and the Hausman test is used to determine the best model for the following step.

\subsubsection{Hausman Test}

Based on the results of data processing, the results of the Hasuman test are obtained, as follows:

Table 10. Hausman Test

\begin{tabular}{lccc}
\hline \multicolumn{4}{c}{ Correlated Random Effects - Hausman Test } \\
\hline \multicolumn{4}{c}{ Pool: DATAPOOL } \\
\hline Test cross-section random effects \\
Test & Chi-Sq. & Chi-Sq. d.f. & Prob. \\
Summary & Statistic & & 0.0000 \\
Cross-secti & 380.337044 & 7 & \\
on random & & & \\
\hline
\end{tabular}

Source: Eviews Data Processing Results, 2021

\subsubsection{Panel Data Regression Equation}

Islamic commercial banks in Indonesia are more stable if their total assets, revenue diversification, and financial inclusion are taken into account, as shown in the following estimation findings. 
Table 11. Estimation of Panel Data Regression Equation (FEM)

Dependent Variable: Y?

Method: Pooled Least Squares

Date: 06/12/21 Time: 04:57

Sample: 20142019

Included observations: 6

Cross-sections included: 8

Total pool (balanced) observations: 48

\begin{tabular}{|c|c|c|c|c|}
\hline Variable & Coefficient & Std. Error & $\mathrm{t}$-Statistic & Prob. \\
\hline $\mathrm{C}$ & -62.31898 & 24.30898 & -2.563620 & 0.0151 \\
\hline $\mathrm{X} 1 ?$ & 5.199467 & 1.826034 & 2.847411 & 0.0075 \\
\hline $\mathrm{X} 2 ?$ & -5.623478 & 2.972448 & -1.891868 & 0.0673 \\
\hline X3? & -0.048830 & 0.049952 & -0.977543 & 0.3354 \\
\hline $\mathrm{Z} ?$ & 0.759245 & 1.326755 & 0.572257 & 0.5710 \\
\hline $\mathrm{X} 1 \mathrm{Z} ?$ & -0.082869 & 0.100263 & -0.826519 & 0.4144 \\
\hline $\mathrm{X} 2 \mathrm{Z} ?$ & 0.644299 & 0.249059 & 2.586932 & 0.0143 \\
\hline X3Z? & 0.006653 & 0.003988 & 1.668222 & 0.1047 \\
\hline \multicolumn{5}{|c|}{ Fixed Effects (Cross) } \\
\hline _ $\mathrm{ACEH}-\mathrm{C}$ & \multicolumn{3}{|l|}{2.557375} & \\
\hline _MUAMALAT_- & \multirow{2}{*}{-4.893591} & & & \\
\hline $\mathrm{C}$ & & & & \\
\hline _BRIS-C & \multicolumn{3}{|l|}{-3.181403} & \\
\hline _BNIS_-C & \multicolumn{3}{|l|}{3.712818} & \\
\hline _MANDIRIS - C & \multicolumn{3}{|l|}{-5.364284} & \\
\hline _MEGAS - C & \multicolumn{3}{|l|}{-1.603273} & \\
\hline _BCAS $-\mathrm{C}$ & \multicolumn{3}{|l|}{7.911796} & \\
\hline _BTPNS - C & \multicolumn{3}{|l|}{0.860562} & \\
\hline \multicolumn{5}{|c|}{ Effects Specification } \\
\hline \multicolumn{5}{|c|}{ Cross-section fixed (dummy variables) } \\
\hline R-squared & 0.965800 & \multicolumn{2}{|c|}{ Mean dependent var } & 3.941044 \\
\hline Adjusted & 0.951291 & \multirow{2}{*}{\multicolumn{2}{|c|}{ S.D. dependent var }} & 3.276429 \\
\hline \multicolumn{3}{|l|}{ R-squared } & & \\
\hline S.E. of regression & 0.723111 & \multicolumn{2}{|c|}{ Akaike info criterion } & 2.439799 \\
\hline Sum squared resid & 17.25537 & \multicolumn{2}{|c|}{ Schwarz criterion } & 3.024550 \\
\hline Log likelihood & -43.55518 & \multicolumn{2}{|c|}{ Hannan-Quinn criter. } & 2.660777 \\
\hline F-statistic & 66.56538 & \multicolumn{2}{|c|}{ Durbin-Watson stat } & 1.266682 \\
\hline Prob(F-statistic) & 0.000000 & & & \\
\hline
\end{tabular}

Source: Eviews Data Processing Results, 2021

The following equation model for the panel data regression in this study is derived from the data in table 11 above: 
$\mathrm{Y}=-62.31898+5.199467 \mathrm{X} 1$ Total Assets $+(-5.623478) \mathrm{X} 2$ Income Diversification $+(-0.048830) X 3$ Financial Inclusion $+0.759245 \mathrm{Z}$ Capital Buffer $+(-0.082869) \mathrm{X} 1 * \mathrm{Z}$ Total Assets * Capital Buffer $+0.644299 \mathrm{X} 2 * \mathrm{Z}$ Income Diversification *Capital Buffer +0.006653 Financial Inclusion*Capital BufferX3*Z $+\mathrm{e}$

\subsubsection{Coefficient of Determination}

Based on the results of data processing, the results of the coefficient of determination are obtained, as follows:

Table 12. Coefficient of Determination

\begin{tabular}{ccccc}
\cline { 2 - 4 } R-squared & 0.965800 & Mean dependent var & 3.941044 \\
\hline $\begin{array}{c}\text { Adjusted } \\
\text { R-squared }\end{array}$ & 0.951291 & S.D. dependent var & 3.276429 \\
\hline $\begin{array}{c}\text { S.E. of } \\
\text { regression }\end{array}$ & 0.723111 & Akaike info criterion & 2.439799 \\
\hline $\begin{array}{c}\text { Sum squared } \\
\text { resid }\end{array}$ & 17.25537 & Schwarz criterion & 3.024550 \\
\hline Log likelihood & -43.55518 & Hannan-Quinn criter. & 2.660777 \\
\hline F-statistic & 66.56538 & Durbin-Watson stat & 1.266682 \\
\hline Prob(F-statistic) & 0.000000 & & \\
\hline
\end{tabular}

Source: Eviews Data Processing Results, 2021

Based on Table 12 above, the coefficient of determination is shown with a value of Rsqure of 0.965800 or $96.58 \%$, this shows that the contribution of the influence of total assets, income diversification, financial inclusion, capital buffer, interaction between total assets* capital buffer, interaction between income diversification* capital buffer and the interaction between financial inclusion* The impact of a capital buffer on the stability of Islamic banks is estimated to be 3.42 percent, with the remaining 3.42 percent resulting from factors beyond the scope of this study.

\subsubsection{F Statistic Test (F Test)}

The f statistic test (f test) results are derived from the data processing results, as follows:

Table 13. F Statistic Test

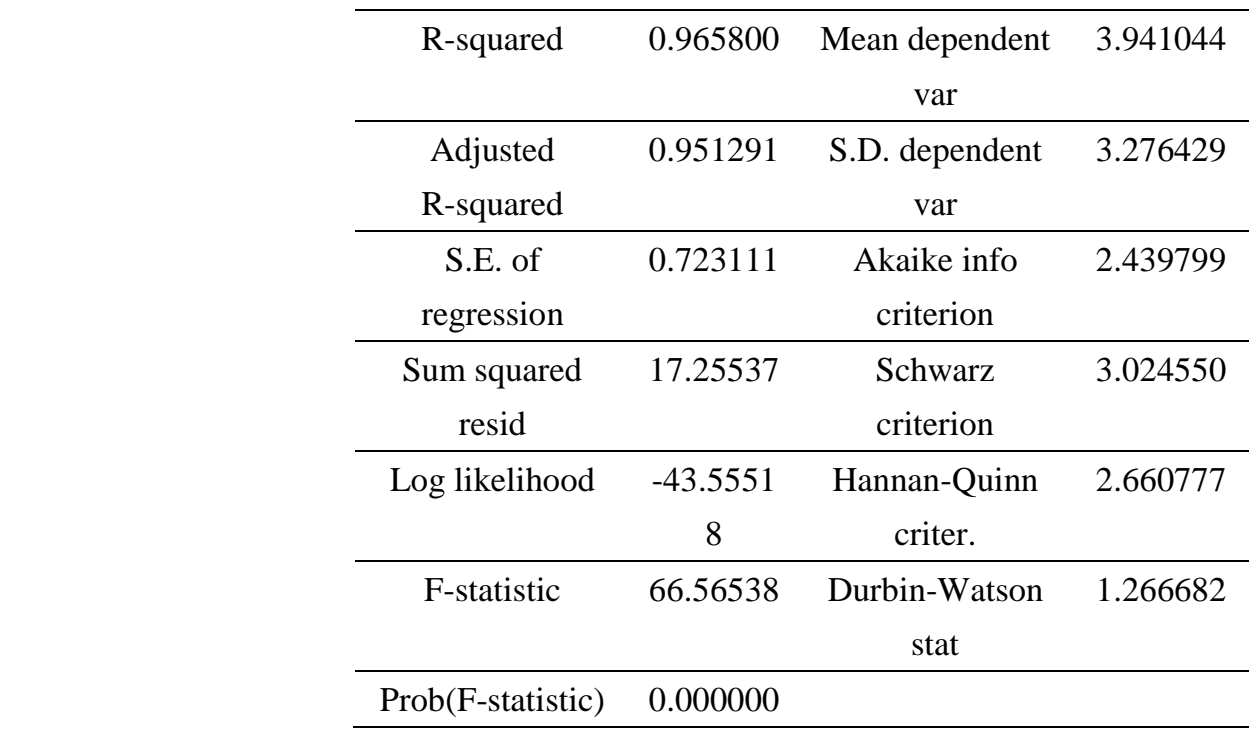

Source: Eviews Data Processing Results, 2021 
On the basis of the findings of simultaneous hypothesis testing and the $\mathrm{f}$ test in Table 13, the f-statistical results of 66.56538 were obtained for the study., with a probability ( $\mathrm{sig}$ ) of 0.000000 , then compared with ftable with df $1=\mathrm{k}=7$ and df $2 \mathrm{n}=48-2=46$, then the results of fcount are obtained of 2.216 , due to the results of statistic $>$ ftable $(66.56538>2.216)$ and probability $(\mathrm{sig}) 0.000000<0.05$, it can be stated that together total assets, income diversification, financial inclusion, capital buffer, interaction between total assets* capital buffer, the interaction between income diversification * capital buffer and the interaction between financial inclusion* capital buffer has a significant effect on the stability of Islamic banks.

\subsubsection{Statistical t Test (t Test)}

Based on the results of data processing, the results of partial hypothesis testing are obtained with the $t$ statistical test ( $\mathrm{t}$ test), as follows:

Table 14. Uji t

\begin{tabular}{ccccc}
\hline Variable & Coefficient & Std. Error & t-Statistic & Prob. \\
\hline $\mathrm{C}$ & -62.31898 & 24.30898 & -2.563620 & 0.0151 \\
\hline $\mathrm{X} 1 ?$ & 5.199467 & 1.826034 & 2.847411 & 0.0075 \\
\hline $\mathrm{X} 2 ?$ & -5.623478 & 2.972448 & -1.891868 & 0.0673 \\
\hline $\mathrm{X} 3 ?$ & -0.048830 & 0.049952 & -0.977543 & 0.3354 \\
\hline $\mathrm{Z} ?$ & 0.759245 & 1.326755 & 0.572257 & 0.5710 \\
\hline $\mathrm{X} 1 \mathrm{Z} ?$ & -0.082869 & 0.100263 & -0.826519 & 0.4144 \\
\hline $\mathrm{X} 2 Z ?$ & 0.644299 & 0.249059 & 2.586932 & 0.0143 \\
\hline $\mathrm{X} 3 Z ?$ & 0.006653 & 0.003988 & 1.668222 & 0.1047 \\
\hline
\end{tabular}

Source: Eviews Data Processing Results, 2021

Based on Table 14 above, it can be concluded that hypothesis testing with $\mathrm{t}$ test, by comparison with $\mathrm{t}$ table obtained from the results of probability $5 \%$ and $\mathrm{df} n=48-2=46$, then the results are 2,013 .

\section{Conclusion}

The following conclusions were reached as a consequence of the findings of the analysis and discussion that was conducted by the researchers:

1. In Indonesia, total bank assets have a statistically significant impact on the stability of Islamic banks. This is based on hypothesis testing with the $t$ test, which yielded tcount (tstatistics)> ttable (2.847411>2.013), and probability (sig) of 0.00750 .05 , after which Ho is rejected and Ha is accepted, respectively.

2. According to the results of hypothesis testing with the $t$ test obtained tcount (tstatistics) $t$ table $(-1.891868$ 2.013 ) and probability (sig) $0.0673>0.05$, Ho is accepted and Ha is rejected, based on the findings of the study.

3. There is no statistically significant effect of financial inclusion on the stability of Islamic banks in Indonesia, as determined by hypothesis testing with the $t$ test, which yielded tcount (tstatistics) $t$ table $(-0.9775432 .013)$ and probability (sig) $0.3354>0.05$, after which Ho is accepted and Ha is rejected, according to the findings.

4. The capital buffer cannot moderate the effect of total assets on the stability of Islamic banks in Indonesia, this is based on hypothesis testing with $t$ test obtained tcount (tstatistics) < ttable $(-0.826519<2.013)$ and probability (sig) 0.4144>0.05, then Ho accepted and Ha rejected.

5. Capital buffer can moderate the effect of income diversification on the stability of Islamic banks, this is based on hypothesis testing with $t$ test obtained tcount (tstatistics)> ttable $(2.586932>2.013)$ and probability (sig) $0.0143<0.05$, then Ho is rejected and Ha is accepted .

6. The capital buffer cannot moderate the effect of financial inclusion on the stability of Islamic banks, this is based on hypothesis testing with $t$ test obtained tcount (tstatistics) < ttable $(1.668222<2.013)$ and probability (sig) $0.1047>0.05$, then Ho is accepted and Ha rejected. 


\section{References}

Ahamed, M. M., \& dan Sushanta, K. M. (2017). Is financial inclusion good for bank stability? International evidence. Journal of Economic Behavior \& Organization. https://doi.org/10.1016/j.jebo.2021.05.027.

Al-Arif, M., \& Rianto, N. (2011). Dasar-Dasar Ekonomi Islam. Solo: Era Adicitra. Intermedia.

Arwinda Putri, N., \& Merkusiwati, N. (2014). Pengaruh Mekanisme Corporate Governance, Likuiditas, Leverage, Dan Ukuran Perusahaan Pada FinancialDistress. E-Jurnal Akuntansi, 7(1), 93-106.

Barth, W. (2016, March). Analyst Earnings Forecast Revisions and the Pricing of Accruals. Review of Accounting Studies 9, 59-96.

Basuki dan Imamudin Yuliadi. (2015). Elektronik Data Prosesing (SPSS. 15 dan EVIEWS 7). Yogyakarta: Danisa Media.

Basuki dan, P. (2017). Analisis Regresi Dalam. Penelitian Ekonomi \& Bisnis: Dilengkapi Aplikasi SPSS \&. EVIEWS. Jakarta: PT Rajagrafindo Persada.

Besma Hamdi dkk. (2012). The Stability of Islamic and Conventional Banks in the MENA Region Countries During the 2007-2012 Financial Crisis.

Čihák, M., \& Hesse, H. (2008). Islamic Banks and Financial Stability: An Empirical Analysis. Journal of Financial Services Research, 38(2), 95-113. https://doi.org/10.1007/s10693-010-0089-0.

Fahmi, I. (2016). Teori dan Teknik Pengambilan Keputusan. Jakarta: Raja Grafindo Persada.

Fauziah, A. F., \& Hidayatin, N. N. (2020). Inklusi Keuangan dan Stabilitas Sistem Keuangan (Bank Z-Score) di Asia Jurusan Administrasi Niaga, Politeknik Negeri Malang, Indonesia. Journal Ekonomi Dan Kewirausahaan, 14(1), 30-47.

Ghozali, I. (2016). Aplikasi Analisis Multivariete Dengan Program. IBM SPSS 23 (Edisi 8). Cetakan ke VIII. Semarang: Universitas Diponegoro.

Gulo. (2010). Metodologi Penelitian. Jakarta: Grasindo.

Gurley, J. (1956). Financial Development and Economic Development. Economic Development Cultural Change, 15(3), 275-168.

Haryanto, S. (2015). Determinan Capital Buffer: Kebijakan Empirik Industri Perbankan Nasional.

Hasanatina, F. H. (2016). Analisis Risiko Kebangkrutan Bank Syariah Dengan Metode ZScore (Studi Kasus pada Bank Umum Syariah di Indonesia Periode 2008-2014). Skripsi. Universitas Diponegoro. Semarang.

\section{Copyrights}

Copyright for this article is retained by the author(s), with first publication rights granted to the journal.

This is an open-access article distributed under the terms and conditions of the Creative Commons Attribution license (http://creativecommons.org/licenses/by/4.0/). 